\title{
Comparative Analysis of Commercial Colloidal Silver Products [Corrigendum]
}

Kumar A, Goia DV. Int J Nanomedicine. 2020;15:1042510434.

The authors have advised they wish to amend the Disclosure statement on page 10433. The correct statement is as follows.

\section{Disclosure}

Ajeet Kumar is an employee of Ames Advanced Materials Corporation. Dan V Goia reports personal fees from Noble Elements LLC, during the conduct of the study; and is one of the inventors of the silver nanoparticles incorporated into Coated Silver, one of the products made by Noble Elements LLC and tested in this study. The associated patent for research leading to this product is US Patent \# 7,842,274 B2, November 30, 2010. The authors report no other potential conflicts of interest in this work.

In addition, the authors have advised that a funding statement should have been included on page 10433 of the published paper. The statement should read as follows.

\section{Funding}

The authors did not receive any specific funding for the reported study.

\section{Publish your work in this journal}

The International Journal of Nanomedicine is an international, peerreviewed journal focusing on the application of nanotechnology in diagnostics, therapeutics, and drug delivery systems throughout the biomedical field. This journal is indexed on PubMed Central, MedLine, CAS, SciSearch ${ }^{\mathbb{R}}$, Current Contents ${ }^{\mathbb{B}} /$ Clinical Medicine,
Journal Citation Reports/Science Edition, EMBase, Scopus and the Elsevier Bibliographic databases. The manuscript management system is completely online and includes a very quick and fair peer-review system, which is all easy to use. Visit http://www.dovepress.com/ testimonials.php to read real quotes from published authors. 